\title{
Application of Case Teaching In Corporate Finance
}

\author{
Sun Dong \\ School of Economics and Management \\ North China Electric and Power University \\ Beijing, China \\ e-mail: sundong@ncepu.edu.cn
}

\author{
Sun Bowen* \\ School of Economics and Management \\ North China Electric and Power University \\ Beijing, China \\ e-mail: bowensun111111@163.com \\ * Corresponding Author
}

\begin{abstract}
Corporate finance theory emerged with the increasingly complex corporate financial decisions and discipline. As an applied discipline, the personnel training of corporate finance should be a combination of theoretical study and practical of the corporate financial decisionmaking, in order to play a good teaching effect. This article mainly discusses the case teaching methods in order to provide a new teaching method and give some suggestion. In this way, students can not only deepen the understanding of financial theory but also get the initial ability for making decisions for enterprise investment management. We illustrate several methods of case teaching and compare each to draw a conclusion. Appropriate introducing of cases into corporate finance teaching can not only mobilize the enthusiasm of the students in the classroom to improve classroom quality, but also help students analyze and solve problems, improve the overall quality of students. Case teaching of corporate finance has kinds of method, we can choose the appropriate method based on the specific teaching situation, so as to achieve better teaching results.
\end{abstract}

Key words-case teaching; corporate finance; application

\section{INTRODUCTION}

Case Method originated from the 1920s, which has been widely used in strong practical and applied disciplines, such as management, law, and medicine.

Corporate finance is strong theoretical and difficult to practice. In the teaching process, students often feel boring and difficult to grasp. Thus we need to seek an intermediary carrier to present a dramatic form of theory to students. Flexible case teaching method can mobilize the enthusiasm of students. It plays a significant role in corporate finance teaching. Corporate Finance Case Method is to put theoretical knowledge to the analysis of typical cases after students mastered the basic knowledge and deepeened the understanding of corporate finance theory through discussion, analysis and explanation of cases, finally improving the capacity of apply corporate finance in real life of students.

Roger Bruning(2006)conducted two studies in multisection introductory child and adolescent development classes to determine effects of introducing abbreviated teaching case studies that were then discussed either in face-to-face or online formats. Students receiving teaching case studies in either format in both classes showed improved ability to critically analyze probe and final cases compared to control participants. Both case study groups in the child development class also showed increased application of psychological concepts in analyzing new cases. No differences in course knowledge were expected as a function of condition and none were found. Hypothesized case-related increases in efficacy for teaching also were not observed. Results were interpreted as supporting a case analysis. ${ }^{[1]}$

Inna Popil(2010)examined the use of case studies as teaching strategies to promote critical thinking. Critical thinking and case studies are defined as teaching method. The benefits and limitations of case studies are also discussed. The literature review investigates research studies that have indicated how case studies facilitate and promote active learning, help clinical problem solving, and encourage the development of critical thinking skills. Using case studies in teaching will assist nurse educators in promoting active learning ${ }^{[2]}$; furthermore, it will help in developing critical thinking skills, which are extremely important for nurses and other health care professionals.

Catalina Ulrich,Anca Nedelcu(2013)presented the case of a team teaching experience at the master degree program at the Faculty of Psychology and Education Sciences, University of Bucharest. The case reflects the experience gained by the two authors over the last three years in carrying out a joint teaching effort. Based on team teaching, the course was interlinked with course, during the second study year. As part of the teaching and research assignments, the students have systematically investigated different kinds of teams in various companies, organizations and institutions. Besides carrying on case studies outside the University environment, students have worked in designated teams and had to critically analyze their own team's dynamics. Students developed monitoring, evaluation and reflection instruments to reflect on the issues, processes and critical elements of teams' dynamics and effectiveness. ${ }^{[3]}$ Grounded on case studies, students' teams designed and delivered training sessions in order to improve the teams they studied as cases or to replicate.

NA.Iahad (2013)found that active learning has attracted strong advocates among faculty looking for alternatives to traditional teaching methods. Case study has been recently introduced as an add-on teaching method in Malaysia. For Universiti Teknologi Malaysia, the Harvard Business School case studies have been selected to be part of the curriculum to inculcate entrepreneurial thinking skills. ${ }^{[4]}$ They discussed the feedback on students' perceptions of students regarding the implementation of case study discussion in the classroom. Findings show that most students show positive perception of using case study as a teaching 
method and agree to learn using the same method in the future.

Andreas Muhar (2006)described experiences with the initiation of transdisciplinarity in academic case study teaching with special reference to regional planning, based on the case study the methodology used, was the evaluation of process steps of the project, based on the general project concept,protocols and questionnaires. They found a key for successful transdisciplinary cooperation is the integration of non - academic actors at an early stage of the project. Important principles are the implementation of a structure of communication and networking in the case study region and the definition of rules of collaboration. The establishment of personal relations and network building is indispensable in order to guarantee a constant and broad exchange between all participants. Joint decision making processes are essential for stable cooperation, which includes a joint problem definition process at the outset of the case study phase as well as joint responsibility for decisions and joint ownership of ideas during and after the case study phase. ${ }^{[5]}$ They found that study teaching also requires thorough preparation of academics. A constant discussion of different approaches to inter and transdisciplinarity, the adaptation of existing conceptual frameworks to the specific requirements of the current case, the building of a committed teaching team and joint teaching of classes are all important. The careful selection of students and their specific preparation with respect to methodology and content are prerequisites for a successful outcome of a transdisciplinary case study.

Christian Riis Flor,Stefan Hirth(2013)analyzed how the liquidity of real and financial assets affects corporate investment. The trade-off between liquidation costs and underinvestment costs implies that low-liquidity firms exhibit negative investment sensitivities to liquid funds, whereas high-liquidity firms have positive sensitivities. ${ }^{[6]}$ If real assets are not divisible in liquidation, firms with high financial liquidity optimally avoid external financing and instead cut new investment. If real assets are divisible, firms use external financing, which implies a lower sensitivity. In addition, asset redeployability decreases the investment sensitivity. Our findings demonstrate that asset liquidity is an important determinant of corporate investment.

\section{CORPORATE FINANCE TEACHING'S GOALS}

\section{A. Corporate finance professionals skills required}

Master modern corporate finance theory and exercise, have a comprehensive understanding of the investment decision-making process and various financing manners and financial instruments, have a solid analytical capacity, have the ability of decision-making and financing, investment and risk management of the company.

\section{B. Training objectives of corporate finance professionals}

Through the study of corporate finance courses, training professionals with both theoretical background and practical ability is the main goal of the Course. Corporate finance professional training case should be designed around the company's main finance theory to expand, and should run through the whole process of teaching. Case teaching is mainly through discussion of the annual reports of listed companies to collect and analyze its governance structure, investment decisions, which is a practice teaching policy for financing and dividend policy for the company's research and design the optimal financial decisions. The purpose is to strengthen students' practical operation and deepen understanding of financial theory connotation, and to enhance students' enthusiasm for learning through case teaching, improve their ability to handle problems. It is an important channel to learn finance theory through case teaching, and it is the main way for students to experience the company's financial decision-making culture. Its purpose is to train students to engage in corporate finance decisions and get preliminary practical skills, so that students can do with confidence before entering the community and engage in work related to the company's financial decisions. The courses are usually completed during the semester senior year and graduate students.

\section{THE NECESSITY OF CASE TEACHING}

The case teaching method is an important way in the corporate finance practical teaching

Corporate Finance Theory emerged in European countries associated with the various issues that arise during the company's operations. Corporate Finance mainly research corporate governance structure, the company's investment decisions, financing decisions, and how companies distribute dividends and other content .In recent years, corporate finance gradually emphasis on corporate finance research academically. As China's economic development is in the transition period, a variety of institutional factors are too complex, companies' initial public is dominated by the government, coupled with the imperfect development of China capital market which lacks effective checks and balances, so there has been a large number of corporate governance issues. ${ }^{[7]}$ For example, the stock rights affinity is widespread in our country, large shareholders' infringement of minority shareholders' interest. Masahiko Aoki cited the words: the research of governance structure of a country must be based on the realities of the country's heritage and history. Due to the special condition of the new normal, we need to develop suitable conditions of the company decision-making mechanism according to China's actual situation seriously.

Corporate finance theory is very important for guiding the company's development and growth, and based on China's national conditions, the corporate finance development must "according to local conditions.

Currently, the corporate finance usually is regarded as a single theoretical teaching curriculum. However it is necessary to combine theory with practice in the financial decisions-making, not only theoretical learning. Case teaching should match personnel training to enable students to become comprehensive talent in "theory and practice" to help improve students' ability to analyze and solve problems

Traditional teaching methods teachers use "cramming method of learning" approach blindly to convey theoretical knowledge to students, thus leading to passive acceptance of the theory. The case teaching is a good solution to this problem. Einstein said, "interest is the best teacher," because the corporate finance case teaching is 
often based on practical economic issues, thus the hot topics can mobilize the students' interest in learning, enhance classroom interaction, change passive learning to active learning. Students participate in learning actively and play the main role instead of the teacher, analysis other aspects of the case and do discussions. The teacher then play a leading role in teaching, choose cases for teaching needs, and also control the situation in class discussions, make best use of the cases, so that each student gets into full play.

To introduce financial institutions, for example, if obeys the original system on its traditional teaching, it will contain a lot of jargon, difficult to understand. For instance, the balance of treasure, students can get practical experiences and a good sense of corporate finance from case teaching. ${ }^{[8]}$ Case questions are easy and interesting, then it will be a dramatic way to help students deepen understanding of financial institutions and the running of it. Case Method created a good, open, interactive learning environment, and enhanced the exchange between teachers and students, active classroom atmosphere, which the traditional teaching has not.

\section{THE CASE TEACHING METHOD AND ITS APPLICATION}

\section{A. Explaining Case Teaching Method}

The corporate finance not only has many financial jargons, many of its principles and methods of operation are also established on the special economic background, it is more difficult to understand from its literal meaning. Then teachers can introduce cases to describe the financial problems of a case and evolution vividly, thereby clarify the principles. The formula of explaining case method is simple and easy to grasp the characteristics, but also there are a few caveats. First, the case introduced should be flexible and varied. After finished the learning of a principle, explain a case to deepen students' impression of the case; the case can also be introduced at the beginning of the chapter, to drawn the principles from case; the case can also be left to the students after school to enhance the ability of independent thinking of students. Second, focus on the key point to explain.

\section{B. Discussing Case Teaching Method}

Discussing case teaching is provided by the teacher to guide students to participate in discussions that worked out solutions to problems. Teachers can propose one or several cases in writing after system teaching of a section or a problem before the lecture to the students to read the case materials and prepare, and then discuss in class. For example, when discussing stocks, the students themselves can use several typical cases of simulation of stock trading and discuss in class and share successful experiences or failure.

Discussion in case teaching is more complicated, not only do teachers need more preparation before class so that students understand some of the relevant background knowledge, but also in the choice of case, to choose cases with strong discussion. At the same time, teachers need to pay attention to guide and give tips, promptly correct the deviation.

\section{Debating Case Teaching Method}

We can also take thematic debate. We need to select some comprehensive cases to organize a debate, divide students into positive and negative groups, through the scene simulation and role playing to give full play to the function of corporate finance case teaching. As explaining the international reserves, we can discuss IPO in China's stock markets. Case debating teaching is a new form of teaching, students' interest is more intense, they can fully express their views, make full use of corporate finance theory knowledge learned to defend their point of view. But this form requires teachers to spend a lot of effort to organize, mobilize students to participate, and maintain good order when debating. The need to control the time for debate is also significant.

\section{ATTENTIONS TO CASE TEACHING}

A. focus on the combination of traditional teaching methods and case teaching methods

The traditional theory of teaching focus on systematic, logical teaching of knowledge, while case teaching focus on the study and research of cases. If it extends the previous traditional teaching methods, students can understand the basic concepts of the system, but the understanding of knowledge only stay on the surface and get inadequate skills. The case teaching method can only teach a handful of knowledge, and cost longer time, if emphasis more on case teaching, it may cause students to ignore grasping of systematic theory thus leading to dispersion of knowledge. Therefore, both the traditional approach and the case teaching should be adopted. When case teaching and traditional teaching combined and complement each other can we cultivate the talent needed for age, see Table I.

TABLE I CASE TEACHING Method ACCOUNTING For TEACHING

\begin{tabular}{|c|c|c|c|}
\hline & Teaching Contents & \multicolumn{2}{|c|}{$\begin{array}{l}\text { Teaching Methods (class } \\
\text { hours/Proportion) }\end{array}$} \\
\hline \multirow[t]{4}{*}{ Step I } & & Lecture & Case-teaching \\
\hline & Budgeting Decision & $14 / 78 \%$ & $4 / 22 \%$ \\
\hline & Financing Decision & $12 / 75 \%$ & $4 / 25 \%$ \\
\hline & Dividend Policy & $10 / 71 \%$ & $4 / 29 \%$ \\
\hline Total & & $36 / 75 \%$ & $12 / 25 \%$ \\
\hline \multirow[t]{4}{*}{ Step II } & & Lecture & Case-teaching \\
\hline & Budgeting Decision & $12 / 67 \%$ & $6 / 33 \%$ \\
\hline & Financing Decision & $10 / 63 \%$ & $6 / 37 \%$ \\
\hline & Dividend Policy & $8 / 57 \%$ & $6 / 43 \%$ \\
\hline Total & & $30 / 63 \%$ & $18 / 37 \%$ \\
\hline \multirow[t]{4}{*}{ Step III } & & Lecture & Case-teaching \\
\hline & Budgeting Decision & $10 / 56 \%$ & $8 / 44 \%$ \\
\hline & Financing Decision & $8 / 50 \%$ & $8 / 50 \%$ \\
\hline & Dividend Policy & $6 / 43 \%$ & $8 / 57 \%$ \\
\hline Total & & $24 / 50 \%$ & $24 / 50 \%$ \\
\hline
\end{tabular}




\section{B. Choosing typical cases}

Choose good case is prerequisite in the teaching. Cases should be typical and the case must be true stories, instead of imagination. Corporate Finance is a strong practical discipline, true cases allow students exposure to the real condition through independent thinking to solve problems. And the selection of cases must adapt to China's national conditions and the social background .

\section{Using multimedia}

Case teaching has a large amount of information, complex content and diverse forms, not only can be textbased, can also be audio-visual materials. Multimedia and other equipment will demonstrate dynamic characteristics of the case and visually, so that students have a clearer understanding of the case. It can also stimulate the enthusiasm of students to participate in then improve the effect of case teaching.

\section{TEACHING GUARANTEE OF CASE TEACHING}

The establishment of corporate finance rules, protection mechanism and norms of professional teaching mode is essential. Establish teaching team according to the requirements: professional person in charge, teachers, counselors.Through the management and guidance of teaching team, so that the teaching process can be more scientific and rigorous. By designing the syllabus, and then come up with feasible cases. This series of programs are applied in the teaching process to enable students to participate. Create quantification appraisal system, each of the indicators should be detailed as quantitative indicators, and create relevant inspection rules, regulations rules. Quantified evaluation system is divided into two parts: a matter of evaluation, ex-post evaluation. By scoring through a series of quantitative indicators, statistical analysis, ranking competitions can greatly encourage the enthusiasm of students, but also allows us to advance more standardized new teaching model courses.

Improve the quality of teaching team in order to strengthen the corporate finance teaching level. Good teachers are prerequisite for the smooth conduct of the learning process. Due to the discipline characteristics of company finance, we need teachers with a solid foundation of professional practice and good skills. For teachers with little practical experience, they should go to financial institutions in batches to study or gain business skills, and strengthen the professional understanding of corporate finance. We can also provides a broader space for students to learn practical skills by hiring part-time teachers from financial institutions, students can also get the latest industry information from them. ${ }^{[9]}$

Increase funding to protect corporate finance case teaching profession smoothly. To guarantee company financial professional case teaching mode operats smoothly, adequate funding is one of the key problems faced. Lack of funds affects enthusiasm of the school and community units. Reduction of investment in case teaching makes it difficult to carry out the case teaching better. Therefore, the relevant departments should pay attention to case teaching model for students, support it and provide sufficient funding to this new way of learning, thus it can proceed more smoothly.

Enhance practice awareness, to achieve the desired results of the case teaching mode. The original intention of the company financial professionals case teaching mode is that, from the perspective of practice, to make finance professional students on campus to develop their own practice through quality courses, so that students can exercise a necessary corporate finance professional analytic skills and problem solving ability, rather than merely learning theory in the ivory tower. And in the learning process, we must continue to encourage students to overcome fear of difficulties and recognize that through this mode of learning, they can get growth and progress, finally entered the society successfully, thus also allow students to gain practical skills and experience to make corporate finance professional case teaching achieve the desired effect, let the teaching operate more smoothly. ${ }^{[10]}$

\section{CONCLUSIONS}

In the learning of finance, case teaching should be applied throughout the whole process of financial personnel training. Reasonable professional training objectives, clear personnel training specifications is the core of case teaching model. Standardized institutional system, high-quality team of teachers, sufficient funding and entrepreneurial spirit of exploration is the back of corporate finance case teaching method. We still need to explore in professional training continuously to further improve and enhance the corporate financial case teaching method, so that a large number of outstanding financial professionals can serve enterprises better, and solve financial decision-making problem.

\section{ACKNOWLEDGMENT}

Supported by Multidirectional interactive case teaching in the curriculum of corporate finance in NCEPU, No2014JG29.

\section{REFERENCES}

[1] Roger Bruning, Kamau O. Siwatu, Xiongyi Liu,Lisa M. Pytlik Zillig, Christy Horn,Stephanie Sic, Deborah Carlson. Introducing teaching cases with face-to-face and computer-mediated discussion: Two multi-classroom quasi-experiments[J]. Contemporary Educational Psychology,2006,33(2):299-326.

[2] Inna Popil. Promotion of critical thinking by using case studies as teaching method[J]. Nurse Education Today,2010,31(2):204-207

[3] Catalina Ulrich,Anca Nedelcu. Team-Teaching and Team Work: Perceptions Amongst Students and Staff (A Case Study) [J]. Procedia - Social and Behavioral Sciences,2013,76:853-857.

[4] Christian Riis Flor,Stefan Hirth. Asset liquidity, corporate investment, and endogenous financing costs[J]. Journal of Banking and Finance,2013,372:474-489.

[5] Andreas Muhar,Ulli Vilsmaier,Michaela Glanzer,Bernhard Freyer. Initiating transdisciplinarity in academic case study teaching. Experiences from a regional development project in Salzburg, Austria[J]. International Journal of Sustainability in Higher Education,2006, 7(3):293-308.

[6] Noorminshah A. Iahad,Marva Mirabolghasemi,Noorfa Haszlinna Mustaffa,Muhammad Shafie Abd. Latif, Yahya Buntat. Student Perception of Using Case Study as a Teaching Method[J]. Procedia - Social and Behavioral Sciences,2013,93(1):2200-2204

[7] Qing Zhou,Robert Faff,Karen Alpert. Bias correction in the estimation of dynamic panel models in corporate finance[J]. Journal of Corporate Finance,2014,25(2):494-513. 
[8] Daiva Jurevičienè,Egidijus Bikas,Greta KeliuotytèStaniulènienè,Lina Novickytė,Petras Dubinskas. Assessment of Corporate Behavioural Finance[J]. Procedia - Social and Behavioral Sciences, 2014, 140:432-439.

[9] Mohammad Al Mutairi,Gary Tian,Helen Hasan,Andrew Tan. Corporate governance and corporate finance practices in a Kuwait
Stock Exchange market listed firm: a survey to confront theory with practice[J]. Corporate Governance,2012, 12(5):595-615.

[10] YANG Yun-feng,SUN Bo-wen. Explore in Experimental Teaching Model of Corporate Finance courses [J].Inner Mongolia Normal University(Education Science Edition),2015,09:67-68. 